Revue des patrimoines

$6 \mid 2005$

Patrimoine en situation : l'Inventaire général entre histoire et prospective

\title{
Découvertes
}

\section{Pierre Curie}

\section{(2) OpenEdition \\ Journals}

Édition électronique

URL : http://journals.openedition.org/insitu/2539

DOI : 10.4000/insitu.2539

ISSN : 1630-7305

Éditeur

Ministère de la culture

Référence électronique

Pierre Curie, « Découvertes », In Situ [En ligne], 6 | 2005, mis en ligne le 17 février 2012, consulté le 01 mai 2019. URL : http://journals.openedition.org/insitu/2539; DOI : 10.4000/insitu.2539

Ce document a été généré automatiquement le 1 mai 2019.

\section{(c) $(1) \Theta \Theta$}

In Situ Revues des patrimoines est mis à disposition selon les termes de la licence Creative Commons Attribution - Pas d'Utilisation Commerciale - Pas de Modification 4.0 International. 


\section{Découvertes}

\section{Pierre Curie}

1 La découverte, c'est la culture surprise, la curiosité nourrie d'un nouvel objet, la satisfaction d'un enrichissement, alors que tout est appelé à disparaître dans le naufrage des temps. Vanité ? Sans doute un peu, mais fierté de bonne foi du découvreur, promu à la reconnaissance par cette pérennisation même.

2 La renaissance des œuvres oubliées est bien, dans l'idée des premiers chercheurs de l'Inventaire, une tâche incombant au service et qui deviendra d'autant plus nécessaire qu'ils ont parfaitement conscience des destructions à venir. Ce qu'ils ignorent encore à leurs débuts, c'est que leur regard évoluera et que des trésors pourront surgir là où ils n'ont rien vu, quarante années plus tôt (un temple tamoul, un cycle art déco...). Non qu'il s'agisse d'un défaut de leurs critères de sélection, mais bien parce qu'en quelques décennies, l'histoire de l'art se sera infiniment ouverte sur la variété du monde, et dans un temps toujours plus proche du nôtre : tout pourrait vraiment devenir patrimoine.

Demeurent les chefs-d'œuvre inexplicablement négligés et retrouvés au gré d'une étude thématique ou topographique (une toile du siècle d'or espagnol, une aiguière précieuse...) La part d'énigme intrinsèque à toute œuvre que révèle ce type de récupération - et il en va de même dans les musées ou sur le marché de l'art - fascine toujours et questionne sur le destin des choses (combien de pertes pour combien de sauvetages ?). Ainsi donc, avec le concours inopiné du hasard, le grand engloutissement ne serait pas inéluctable. 


\section{AUTEUR}

\section{PIERRE CURIE}

Conservateur du patrimoine. Sous-direction de l'archéologie, de l'ethnologie, de l'inventaire et du système d'information. pierre.curie@culture.gouv.fr 